\title{
The first case of human autochtonous subconjunctival dirofilariosis in Poland and MALT lymphoma as possible consequence of this parasitosis
}

\author{
Piotr K Borkowski ${ }^{*}$, Grzegorz Rymkiewicz², Joanna Golebiewska ${ }^{3}$, Nestor Nestoros ${ }^{3}$, Joanna Romejko-Jarosinska ${ }^{4}$,
} Hanna Zarnowska-Prymek', Aleksander Masny ${ }^{5}$, Jakub Palucki ${ }^{6}$ and Danuta Cielecka, ${ }^{5,7}$

\begin{abstract}
The first case of human dirofilarosis in Poland was recorded in 2007. Until that time our country was free of Dirofilaria repens. Recent studies show that $21,4-60 \%$ of dogs in Warsaw region harbour microfilariae, therefore it is becoming a growing problem in Central Europe.

In April 2013 a subconjunctival D. repens was removed from the eye of 61-year-old woman. It was the twenty first case of this disease in Poland, the third case of eye dirofilaria and the fourth autochtonous case. The patient had never been abroad, so it was the first case of autochtonous human ocular dirofilariosis in Poland. Nine months after the D. repens had been removed, a MALT lymphoma was discovered. In the article we discuss whether a MALT lymphoma of the lacrimal gland of the eye, previously affected by the parasite, may be the consequence of the invasion.
\end{abstract}

Keywords: Dirofilaria repens, Human, Poland, Autochtonous species, MALT lymphoma, Wolbachia

\section{Introduction}

Dirofilariosis is a parasitic infection diagnosed mainly in dogs and less frequently in cats or free living carnivores. Occasionally dirofilariosis can be the zoonotic human infestation. However, this happens rarely, when Culex, Aedes or Anopheles mosquitoes, during blood consumption, inject microfilariae into human circulation. In Poland, Dirofilaria (Nochtiella) repens (Railiet et Henry, 1911) is responsible for the disease in the form of subcutaneous nodules and of subconjunctival localization [1-3]. The first cases of dirofilarosis in Poland was recorded in 2007 [2,4]. Until then, Poland and other neighboring Central European countries were free of $D$. repens. Initially, we suspected that all of the cases of human dirofilariosis were brought from abroad. Recent studies have showed that $21,4 \%$ up to $60 \%$ (average $25,8 \%$ ) of dogs residing in Warsaw area harbour microfilariae. Such percentage is almost equal to the one in

\footnotetext{
* Correspondence: piotr.k.borkowski@gmail.com

'Department of Zoonoses and Tropical Diseases, Medical University of Warsaw, Warsaw, Poland

Full list of author information is available at the end of the article
}

Italy, a traditional endemic region, therefore atochtonous dirofilariosis it is a growing problem in Poland and Central Europe [4-7].

Below the case of lacrimal gland MALT lymphoma which was discovered nine months after removing of $D$. repens from conjunctiva of the affected eye is presented.

\section{Case report}

In July 2012, a 61-year-old woman came to the Ophthalmology Department of Warsaw Medical University with the history of one day pain and itching in her left eye. A subconjunctival worm was well-visible (Figure 1). An ophthalmologist removed the worm surgically and referred the patient to the Zoonoses and Tropical Diseases Department for further investigation. It was $11 \mathrm{~cm}$ long and $0,47 \mathrm{~mm}$ wide nematode. Microscopic investigation proved that it was a young female with uterus filled with oocytes. Characteristic longitudinal ridges and delicate transverse stripes typical for $D$. repens cuticle were recognized (Figure 2).

Dirofilaria DNA was amplified using DR COI-F1 and DR COI-R1 primers using real-time PCR. Positive 


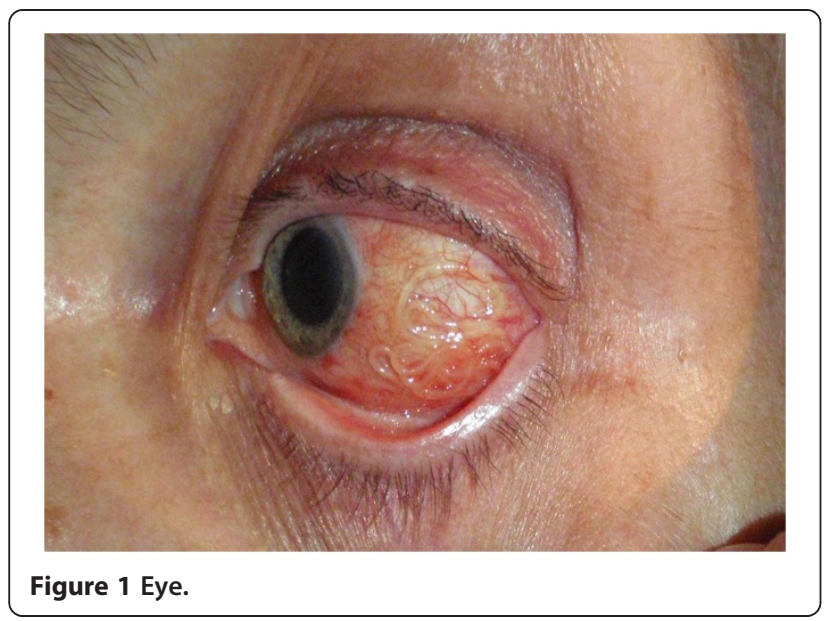

results of the amplification of the gene of the first subunit of cytochrome oxidase and the analysis of melting curves of PCR products confirmed that our nematode belonged to the species of $D$. repens [8].

Microfilariae in patient's peripheral blood were not detected. ELISA test for human tropical filariosis (Bordier, Switzerland, which use Acanthocheilonema vitae somatic antigens) and for Toxocara canis were negative. There was no eosinofilia. Before obtaining all these results, in case of microfilariae presence, we undertook the albendazole treatment [9]. A few days after the surgery, the patient's eye was healed, although occasionally she reported a delicate pain. The patient's dog was also examined for presence of microfilariae, but the results were negative.

In April 2013 the patient returned to the Zoonoses and Tropical Diseases Department with the pain in the same eye. Despite conjunctivitis we did not find any abnormalities, so she was referred to the Ophthalmology Department. Within one week she developed periorbital edema and diplopia. The ultrasound and MRI revealed

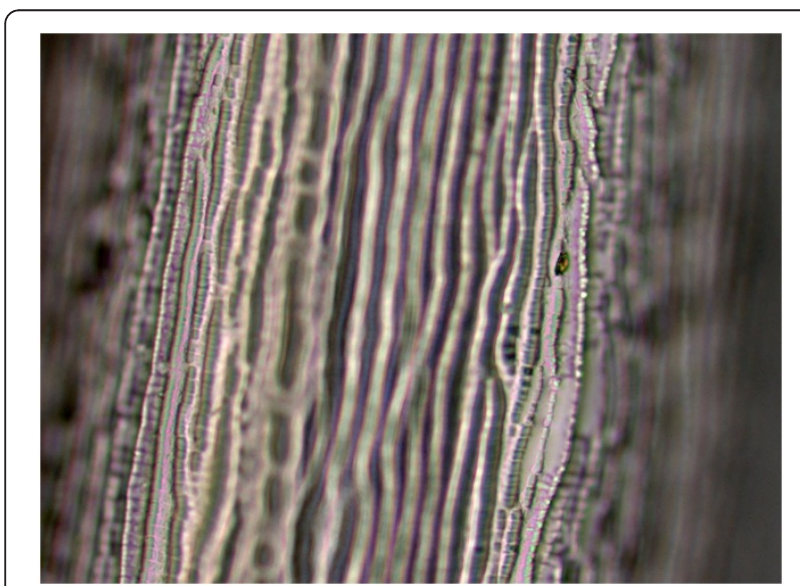

Figure 2 Stripes and ridges. an enlarged lacrimal gland (Figure 3). Tumor samples were taken for histopatological examination [10]. The diagnosis was extranodal marginal zone lymphoma of mucosa associated tissue (MALT lymphoma) (Figure 4). The patient was referred to the Institute of Oncology for further treatment. Until present (July 2014), she undertook the six R-COP (Rituximab, Cyclophosfamide, Vincristine, Prednisone) immunochemotherapy courses and her status remains excellent.

\section{Discussion}

The patient resides near Warsaw and she has never been abroad, so the case is autochtonous. It was the twenty first case of dirofilariosis, the third case of the eye dirofilaria and the fourth autochtonous case in Poland, but the first ocular and autochtonous. The first case of human dirofilarosis in Poland was recorded in 2007. Until then, Poland and neighboring Central European countries were free of D. repens. At first, we considered all human cases to be transferred from abroad, but currently we know that many of them are autochtonous [1]. The first cases of animal and human dirofilariosis in Poland were described only in Warsaw surroundings (Mazowieckie Province). Later studies detected microfilariae in dogs blood of all regions, but the largest percentage is still in Mazowieckie Province- 25,8\% average [5]. This region is the richest in Poland, so people from here travel most frequently. Similar percentage of dogs are affected in traditional endemic regions in Italy even temperatures in Poland are lower. Autochtonous dirofilariosis is becoming a growing problem in Poland. The situation described is the result of global warming or it might be also the result of the fact that just in 2007 Poland had joined the Schengen group (EEC no-borders countries). Since then the number of people travelling with their dogs to the endemic regions in Mediterranean region have grown extensively $[11,12]$.

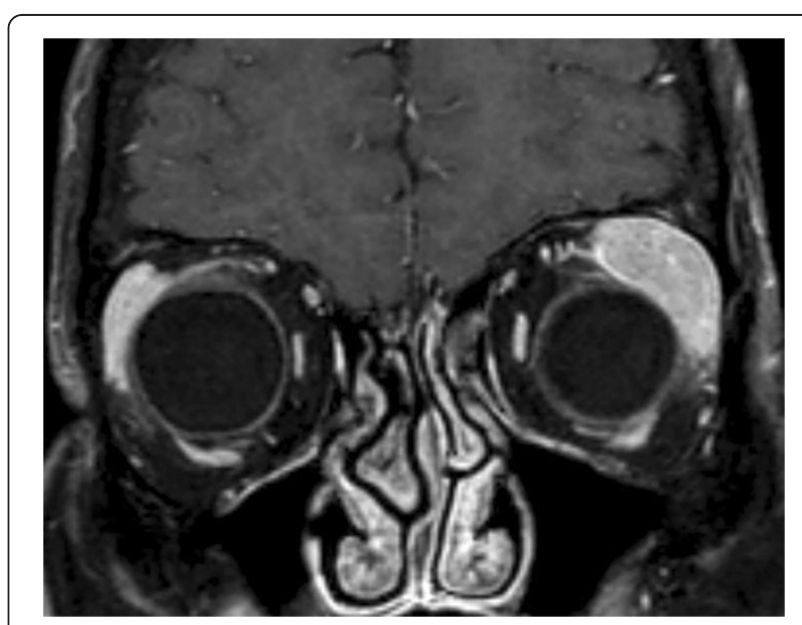

Figure $3 \mathrm{MRI}$ of orbital tumor. 


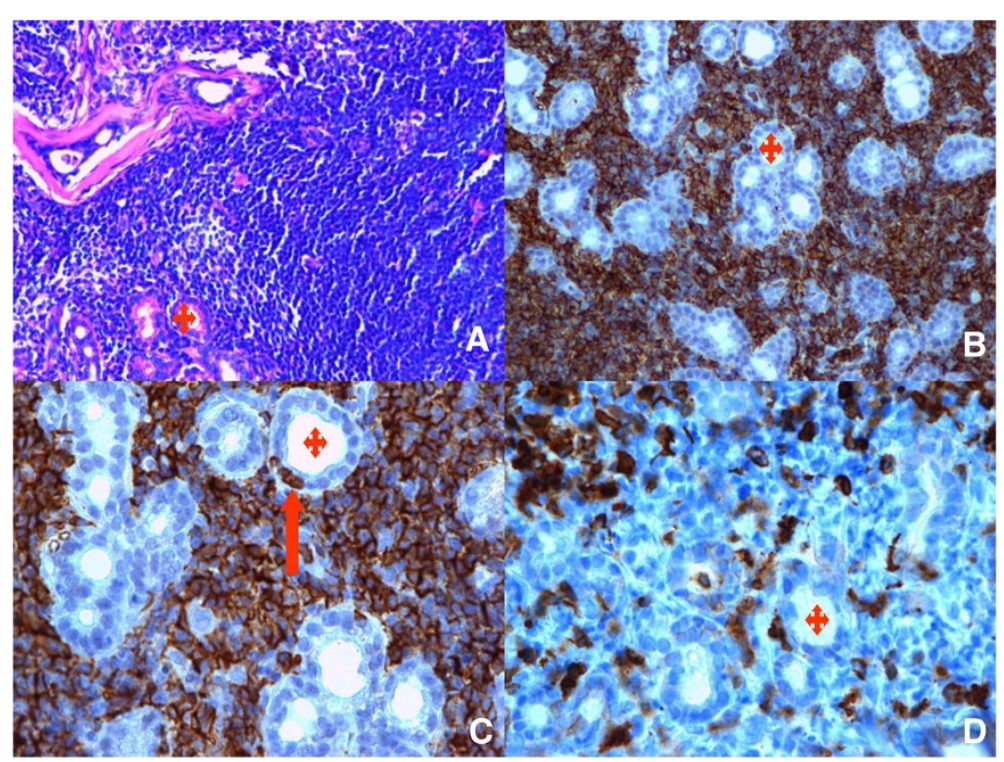

Figure 4 Morphological and immunohistochemical features of extranodal marginal zone lymphoma of mucosa-associated lymphoid tissue (MALT lymphoma) of ocular adnexal. A) Monotonous population of small centrocytic cells with scant cytoplasm (ocular adnexal section HE, ×200 magnification), B) MALT lymphoma cells express CD20 (+).There are scattered glands of ocular adnexal (red stars in all figures) (CD20 immunostain $\times 200$ magnification), C) MALT lymphoma with few lymphoepithelial lesions - the tumour cells infiltrate the glands (red arrow) (CD20 immunostain $\times 400$ magnification), D) MALT lymphoma with low number of normal T CD3 (+) lymphocytes (CD3 immunostain $\times 400$ magnification). In addition to the figures, the lymphoma cells are negative for CD43 (-) and CD5 (-). Plasmacytic differentiation is present in approximately $20 \%$ of MALT cells with CD138 (+) expression on this subpopulations of lymphoma cells. Tumour cells show kappa (+)/lambda (-) light chain restriction by immunohistochemical reaction.

Parasites most frequently live in subcutaneous tissue of the human body. Italian authors estimate that in about $30 \%$ of cases worms are situated in ocular region, whereas similar literature from Ukraine estimate that up to $40 \%$ of cases are located there $[7,13]$. In this localization infection may be periorbital, subconjunctival or most rarely intraocular $[10,14]$. In literature we found two cases where worms were removed from lacrimal gland: one was in China and another one in Croatia [15,16].

Microfilarial migration lasts months before reaching maturity and adult parasite can persist 2-4 years in human body. Granulomatous inflammation around parasite forms usually a tender nodule. It produces local irritation, edema, sometimes itching. In literature it was described several times, that these nodules were initially taken under the consideration as a malignancy, and only later histological assessment elucidate their true origin [17]. This patient did not feel any under-the-skin movement so the worm grew behind her eye ball, possibly in the lacrimal gland. There was no eosinofilia, itching nor pain and the serological tests were negative so in this case inflammation was not intense but long-lasting.

There are a number of situations, where parasites (from the trematoda) are responsible for carcinogenesis: eggs of Schistosoma haematobium in urinary bladder wall and eggs of S. japonicum in a large intestine wall are responsible for squamous cell carcinomas, Opisthorchis and Clonorchis can cause cholangiocarcinoma [18]. Until recently there was no data of cause and effect linkage between helminths and malignant transformation in the orbit area. Tumor was discovered (became clinically significant) nine months after the worm was removed, but we can't exclude, that the transformation occurred during parasite presence.

On the other hand, in many cases of MALT lymphoma, there is a history of a chronic inflammatory disorders that results in accumulation of extranodal lymphoid tissue. The chronic inflammation may be the result of infection, autoimmunity or other unknown stimuli. Examples of infectious organisms that may cause accumulation of mucosa associated tissue preceding MALT lymphoma include: Helicobacter pylori (gastric MALT lymphoma), Chlamydia psittaci (ocular adnexal MALT lymphoma) and Borrelia burgdorferi (cutaneus MALT lymphoma) [19-22]. At least in ocular MALT lymphomas, there is great variation in the strength of these associations that might relate in part to geographic diversity [23]. There is a documented coexistence of bacterial endosymbiont Wolbachia with $D$. repens $[24,25]$. Does Wolbachia, as an unknown stimulus, play a role in pathogenesis of MALT lymphoma in this case? 


\section{Conclusions}

1. The number of human cases of dirofilariosis in Poland and Central Europe will increase in the future approaching the level similar in the traditional endemic regions. This subsequent autochtonus case supports this hypothesis.

2. It has been proved that increasing cases of dirofilariosis in Central Europe resulted from global warming, but it is worth to note that it might also be the result of increased traveling of people with their dogs after Poland and neighboring countries have joined the Schengen group in 2007.

3. We postulate that Dirofilaria repens invasion and/or Wolbachia could play a role in pathogenesis of ocular MALT lymphoma as possible factor.

\section{Consent}

Written informed consent was obtained from the patient for publication of this report and any accompanying images.

\section{Competing interests}

The authors declare that they have no competing interests.

\section{Authors' contributions}

PKB: conceived the idea, responsible for the patient care, literature analysis, pictures and manuscript preparation. GR: histopathologist, responsible for immunohistochemical assessment, literature analysis, manuscript preparation. JG, NN and JR-J: responsible for the patient treatment. HŻ-P; parasitologist responsible for the initial worm assessment. AM: parasitologist responsible for PCR parasite assessment and some picture. JP: radiologist responsible for analyzing and preparing of MR picture. DC: parasitologist responsible for final parasite assessment, some picture, literature analysis and manuscript preparation. All authors read and approved the final manuscript.

\section{Author details}

${ }^{1}$ Department of Zoonoses and Tropical Diseases, Medical University of Warsaw, Warsaw, Poland. ${ }^{2}$ Flow Cytometry Laboratory, Department of Pathology and Laboratory Diagnostics, The Maria Skłodowska-Curie Memorial Cancer Center and Institute of Oncology, Warsaw, Poland. ${ }^{3}$ Department of Ophthalmology, Medical University of Warsaw, Warsaw, Poland. ${ }^{4}$ Department of Lymphoid Malignancies, The Maria Skłodowska-Curie Memorial Cancer Center and Institute of Oncology, Warsaw, Poland. ${ }^{5}$ Department of Medical Parasitology, National Institute of Public Health - National Institute of Hygiene, Warsaw, Poland. ${ }^{6}$ Department of Radiology, The Maria Skłodowska - Curie Memorial Cancer Center and Institute of Oncology, Warsaw, Poland. ${ }^{7}$ Department of General Biology and Parasitology, Medical University of Warsaw, Warsaw, Poland.

Received: 13 August 2014 Accepted: 9 December 2014 Published: 7 January 2015

\section{References}

1. Cielecka D, Żarnowska-Prymek H, Masny A, Salamatin R, Wesołowska M, Gołą E: Human dirofilariosis in Poland: the first cases of autochtonus infections with Dirofilaria repens. Ann Agric Environ Med 2012, 19(3):445-450.

2. Zarnowska-Prymek $H$, Cielecka D, Salamatin R: Dirofilariasis first time described in Polish patients. Przegl Epidemiol 2008, 62:547-551.

3. Wesołowska M, Kisza K, Szalinski M, Zielinski M, Okulewicz A, Misiuk-Hojło M, Szostakowska B: First case of heterochtonus subconjunctival dirofilariasis described in Poland. Am J Trop Med Hyg 2010, 83(2):210.
4. Demiaszkiewicz AW, Polańczyk G, Pyziel AM, Kuligowska I, Lachowicz J: The first foci of dirofilariosis of dogs evoked by Dirofilaria repens Railliet et Henry, 1911 in central Poland. Wiad Parazytol 2009, 55(4):367-370.

5. Demiaszkiewicz AW: Dirofilaria repens Railliet et Henry, 1911- a new parasite acclimatized in Poland. Ann Parasitol 2014, 60(1):31-35.

6. Simón F, Siles-Lucas M, Morchón R, Gonzalez-Miguel J, Mellado I, Carretón E, Montoya-Alonso JA: Human and Animal Dirofilariasis: the Emergence of a Zoonotic Mosaic. Clin Microbiol Rev 2012 25(3):507-544.

7. Pampiglione S, Rivasi F, Angeli G, Boldorini R, Incensati RM, Pastormerlo M, Pavesi M, Ramponi A: Dirofilariasis due to Dirofilaria repens in Italy, an emergent zoonosis: report of 60 new cases. Histopathology 2001, 38(4):344-354

8. Masny A, Żarnowska-Prymek H, Cielecka D, Sałamatin R, Gołąb E: Procedures for species identification of the nematodes belonging to Dirofilaria genus in the clinical material isolated from humans. Med Dosw Mikrobio 2010, 62(2):181-188.

9. Supriaga VG, Tsybina TN, Denisova TN, Morozov EN, Romanenko NA, Starkova TV: The first case of diagnosis of dirofilariasis from the microfilariae detected in the human subcutaneous tumor punctate. Med Parazitol (Mosk) 2004, (4):6-8.

10. Ilyasov B, Kartashev V, Bastrikov N, Morchón R, González-Miguel J, Simón F: Delayed diagnosis of Dirofilariasis and complex ocular surgery. Russia Emerg Infect Dis 2013, 19(2):326-328.

11. Miterpakovza M, Hurnikova Z, Antolova D, Dubinsky P: Climate changes implicated for Dirofilaria dissemination in Slovakia. Wiad Parazytol 2009, 55(4):429-431.

12. Genchi C, Mortarino M, Rinaldi R, Traldi G, Genchi M: Changing climate and changing vector- borne disease distribution: the example of Dirofilaria in Europe. Vet Parasitol 2011, 176(4):295-299.

13. Sałamatin RV, Pavlikovska TM, Sagach OS, Nikolayenko SM, Kornyushin W, Kharchenko VO, Masny A, Cielecka D, Konieczna-Sałamatin J, Conn DB, Gołąb E: Human dirofilariasis due to Dirofilaria repens in Ukraine, an emergent zoonosis: epidemiological report of 1465 cases. Acta Parasitol 2013, 58(4):592-598.

14. Otranto $D$, Eberhard ML: Zoonotic helminths affecting human eye. Parasit Vectors 2011, 4:41.

15. Yuen KSC, Tse MWI, Choi PCL, Chan WM, Lam DSC: Unusual presentation of dirofilariasis as a lacrimal mass. Eye 2004, 18:959-960.

16. Juri J, Kuzman T, Stiglmayer N, Tojagić M: A case of lacrimal gland dirofilariasis. Ophthalmologica 2007, 221(3):204-206.

17. Henderson BM, Hunt CH, Eckel LJ, Schwartz KM, Diehn FE, Pritt BS, Schembri Wismayer DJ, Garrity JA: Intramuscular Dirofilariasis mimicking an orbital metastasis in a patient with breast cancer. Case Rep Radio/ 2012, 2012:103154.

18. Samaras V, Rafailidis PI, Mourtzoukou EG, Pappas G, Falagas ME: Chronic bacterial and parasitic infections and cancer: a review. J Infect Dev Ctries 2010, 4(5):267-281.

19. Collina F, De Chiara A, De Renzo A, De Rosa G, Botti G, Franco R: Chlamydia psittaci in ocular adnexa MALT lymphoma: a possible role in lymphomagenesis and a different geographical distribution. Infect Agent Cancer 2012, 7:8

20. Goodlad JR, Davidson MM, Hollowood K, Batstone P, Ho-Yen DO: Borrelia burgdorferi-associated cutaneous marginal zone lymphoma: $\mathrm{A}$ clinicopathological study of two cases illustrating the temporal progression of B. burgdorferi-associated B-cell proliferation in the skin. Histopathology 2000, 37:501-508.

21. Isaacson PG, Chott A, Nakamura S, Müller-Hermelink HK, Harris NL, Swerdlow SH: Extranodal marginal zone lymphoma of mucosa-associated lymphoid tissue (MALT lymphoma). In WHO classification of tumors of haematopoietic and lymphoid tissues. Edited by Swerdlow SH, Campo E, Harris NL, Jaffe ES, Pileri SA, Stein H, Thiele J, Vardiman JW. Lyon: IARC; 2008:214-217.

22. Lima KS, Albuquerque W, Arantes VN, Drummond-Lage AP, Coelho LG Helicobacter pylori and t $(11 ; 18)(\mathrm{q} 21 ; \mathrm{q} 21)$ translocation in gastric MALT lymphoma. Arg Gastroenterol 2014, 51(2):84-89.

23. Chanudet E, Zhou Y, Bacon CM, Wotherspoon AC, Muller-Hermelink HK, Adam P, Dong HY, De Jong D, Li Y, Wei R, Gong X, Wu Q, Ranaldi R, Pileri SA, Ye H, Hamoudi RA, Liu H, Radford J, Du MQ: Chlamydia psittaci is variably associated with ocular adnexal MALT lymphoma in different geographical regions. J Pathol 2006, 209:344-351. 
24. Grandi G, Morchon R, Kramer L, Kartashev V, Simon F: Wolbachia in Dirofilaria repens, an agent causing human dirofilarasis. J Parasitol 2008, 94(6):1421-1423.

25. Kramer LH: Immunopathogenesis of filarial infections in dogs and cats: a role for Wolbachia endosymbiont? In Dirofilaria immitis and D. repens in dog and cat and human infections. Edited by Genchi C, Rinaldi L, Giuseppe C. Naples: Litografia Vigilante srl, Rolando Editore; 2007:67-73.

doi:10.1186/1750-9378-10-1

Cite this article as: Borkowski et al.: The first case of human

autochtonous subconjunctival dirofilariosis in Poland and

MALT lymphoma as possible consequence of this parasitosis. Infectious

Agents and Cancer 2014 10:1.

\section{Submit your next manuscript to BioMed Central and take full advantage of:}

- Convenient online submission

- Thorough peer review

- No space constraints or color figure charges

- Immediate publication on acceptance

- Inclusion in PubMed, CAS, Scopus and Google Scholar

- Research which is freely available for redistribution 